\title{
The Role of Cognitive Engagement in Self-Censoring Process of Racial Predispositions
}

\author{
Ryu, Jaesung \\ (Seoul National University)
}

$\langle$ CONTENTS〉

I. Introduction

II. The Uneven Effects of Anti-black Attitudes and Racial Norms

III. Self-Censoring Process and Cognitive Engagement

IV. Defining Cognitive Engagement in a Survey Context
1. Data and Measures

2. Dependent Variables

3. Independent Variables

V. Models

VI. Results

VII. Discussion

- Keyword: symbolic racism, racial norm, cognitive engagement, self-censoring effect

\section{【ABSTRACT】}

This study examines how cognitive engagement affects the public opinion of white citizens concerning racially targeted policies. An extensive body of research shows that racial predispositions are the major ingredients for whites' opposition to racially targeted policies. On the other hand, literature on self-censoring process indicates that hasty stereotypical responses can be suppressed by heightened cognitive engagement with the judgmental tasks at hand. Relying on the National Election Studies survey data of 1996 and 2004, I demonstrate that those with high levels of cognitive engagement with race issues broached during the survey interview are significantly less likely to be influenced by their racial predispositions. This result suggests that the effects of racial predispositions on racial policy preferences are moderated by greater cognitive engagement with the issue at hand. 


\section{I . Introduction}

Explaining why individuals who are committed to the principle of racial equality continue to oppose race-targeted public policies has been the subject of extensive research and intense debate by scholars over the past quarter-century (see Sears et al. 2000; Kinder and Sanders 1996; Sidanius et al. 1997; Bobo and Hutchings 1996; Sniderman and Piazza 1993). There is a general agreement among scholars that making judgments on race-targeted policy issues is marked by a tension between "emotions driven by racial predispositions" ${ }^{11}$ and "values and self-concepts best characterized by the principle of racial equality."

Three points of agreement stand out. First, white Americans acquire anti-black attitudes early and firmly. Almost all white Americans have somewhat, yet genuinely, negative attitudes toward blacks (Sears et al. 2000; Sidanius et al. 1997; Federico and Sidanius 2002; Kinder and Sanders 1996). Second, although cultural norms have become increasingly negative toward straightforward racial prejudice and stereotypes, and support for the principle of racial equality has increased, support for policies to realize equality have either remained the same or fallen off (Schuman, Steeh, and Bobo 1998). Third, when white Americans are asked about racial policies, the tension between antiblack attitudes and racial norms creates ambivalence, instability, and inconsistency (Stoker 1998; Hochschild 2001; Entman and Rojecki 2001; Kuklinski, Cobb, and Gilens 1997; Edsall and Edsall 1991). ${ }^{2}$

1) By racial predispositions, I refer to white citizens' attitudes toward blacks that include racial resentment(the juncture of anti-black attitudes and traditional American values, see Kinder and Sanders 1996), racial prejudice(the attribution of a strong, openly expressed, negative evaluation of African Americans as a group and individuals, see Kinder and Sears 1981; McConahay and Hough 1976; Sears and Kinder 1971; Sears and McConahay 1973), and racial stereotype(not just a heuristic device to simplify experience, but destructive forces that historically have evoked punitive and discriminatory responses to racial groups; a substantial minority of white Americans views blacks as a "hostile" and "lazy" underclass of the undeserving poor, see Hurwitz and Peflley 1998; Bobo 1988; Schuman et al. 1988). The concepts of racial resentment, prejudice, and stereotype are typically viewed as being interrelated although the precise relationships among them are complicated. For instance, it is unclear whether racial resentment derives from racial prejudice or ideological principles. In addition, racial resentment means different things to white liberals and conservatives (Feldman and Huddy 2005). Some scholars hold that a racial stereotype is the cognitive component of racial prejudice(Harding, Proshansky, Kutner, and Chein 1969; Secord and Backman 1974) while others suggest that racial stereotype is functional for the individual allowing rationalization of his or her racial prejudice(Allport 1954; LaViolette and Silvert 1951; Saenger 1953; Simpson and Yinger 1965). On the other hand, it seems clear that while most white Americans are not bigots, many of them hold racially predisposed attitudes that are early-learned and cognitively simple(Carmines and Stimson 1989; Kinder and Sears 1981; Sears 1988; Katz and Hass 1988; see also Rogers and PrenticeDunn 1981; Gaertner and Dovidio 1986). 
It should be noted, however, that anti-black attitudes have been considered a primary factor in determining policy judgments on race matters. While not disputing the importance of this argument, I contend that the focus on anti-black attitudes has underestimated the role of racial norms, undermining understanding of the formation of racial policy preferences. I also contend that taking cognitive engagement with the issues into account yields a more precise understanding of the formation of racial policy preferences.

Previous studies implicate the role of cognitive engagement in the formation of racial policy preferences. For instance, some individuals, including those who are racially prejudiced or hold strong racial stereotypes, tend to suppress their expressions of prejudiced or stereotyped policy preferences if they care about how others view them (Berinsky 1999, 2002; Krysan 1998; Kawakamin et al. 2000). Similarly, Mendelberg (2001) shows that

unconscious priming can be controlled if people are motivated and aware enough to guard against it... All whites know the content of racial stereotypes and thus all whites are susceptible to racial priming, but some are more powerfully motivated to control it while others are less so (123-24).

In short, self-motivated controlling over racial stereotypes, impression management, or social desirability effects can lead some individuals to control or suppress their antiblack attitudes and respond more in-line with egalitarian beliefs. Thus, racial attitudes might be more malleable than previously thought, and racial policy preferences might be conditional on the extent to which individuals are motivated to manage or control their anti-black attitudes. This conclusion is compatible with the proposition that social judgments are determined by whether individuals have controlled, systematic decisionmaking processes or automatic, heuristic ones (Devine 1989; Devine et al. 2002; Fazio and Dunton 1995).

In this study I examine the interaction between anti-black attitudes and cognitive engagement, focusing on whether, and to what extent, cognitive engagement with judgmental tasks in survey processes moderates the impact of anti-black attitudes on

2) Edsall and Edsall(1991) conclude that "race is no longer a straightforward, morally unambiguous force in American politics; instead, considerations of race are not deeply imbedded in the strategy and tactics of politics, in competing concepts of the function and responsibility of government, and in each voter's conceptual structure of moral and partisan identity"(53). See also Sniderman and Piazza(1997) and Sniderman and Carmines(1993). 
policy judgments on race matters. I begin with a brief review of the existing literature on the tension between anti-black attitudes and racial norms. Then I present theories of self-censoring processes of racial attitudes. I argue that the impact of anti-black attitudes and racial norms on racial policy preferences is contingent upon the extent to which individuals cognitively engage in judgmental tasks at hand. I test this hypothesis, proposing a measure of cognitive engagement in the survey context as a focal independent variable. Finally, I present the findings and discuss the implications of the analysis.

\section{The Uneven Effects of Anti-black Attitudes and Racial Norms}

White Americans prize the principle of racial equality while also holding negative racial attitudes toward black Americans (Bobo and Kluegel 1993; Jackman and Muha 1984; Kinder and Sanders 1996; Sears 1988; Schuman et al. 1997; Mendelberg 2001). The tension between the racial norm and anti-black attitudes depends upon the contexts in which the issues are raised and framed (Nelson 2004; Stoker 1998; Kuklinski, Cobb, and Gilens 1997). In some contexts where the racial norm is presented, white Americans appear unprejudiced and are likely to support the race-targeted public policies. Krysan (1998) finds that the normative climate presently salient creates social desirability pressures, resulting in an overstatement of liberal racial attitudes, especially by more educated respondents. In other contexts when complete privacy is guaranteed (e.g., when questionnaires are mailed to and returned by respondents without any interviewer) or when racial cues designed to activate or prime anti-black attitudes are provided, white Americans express less liberal attitudes and are likely to oppose racetargeted public policies (Krysan 1998; Dovidio and Fazio 1992; Feagin and Sikes 1994; Bargh 1994, 1999; see also Mendelberg 2001).

It is important to note here that in normal conditions anti-black attitudes are more present in the minds of white Americans than the racial norm is, and that racial cues are more frequently available from the environment than the racial norm is (Kinder and Sanders 1996; Sears and Citrin 1985; Kinder and Mendelberg 1995; Schuman et al. 1997). On this score, three points deserve some emphasis. First, as Sears and his colleague state, "racial predispositions dominate all other factors in terms of individual correlations or regression coefficients, and in their capacity for explaining variance in policy preferences" (Sears et al. 1997, 44). Second, whites' anti-black attitudes draw upon the residues of commonly held negative socialization processes in (white) American culture, 
so that they are evoked unconsciously or automatically. Therefore, racial framing or cues need not be explicit. Instead, subtle racial framing or cues that are implicit or with deniability are strong enough to evoke racial predispositions (Mendelberg 2001). Third, anti-black attitudes are acquired early in life and persist into adulthood, so they are embedded in (white) American culture (Schuman et al. 1997; Sears et al. 1997).

It follows that white Americans must put in an extensive effort and develop effective regulatory strategies in order to control or suppress their life-long racial predispositions. It is improbable, if not impossible, for ordinary white citizens to censor or regulate their anti-black attitudes in the normal conditions where the racial norm is not present or racial cues are readily available. I now turn to discuss the literature on individual-level mental mechanisms through which the tension between racial predispositions and racial norm works in producing racial policy preferences.

\section{Self-Censoring Process and Cognitive Engagement}

Scholars in social psychology have long debated the mental mechanisms underlying social judgments, focusing on the concepts of automaticity, control, consciousness, and intention (see Uleman and Bargh et al. 1989; Hassin, Uleman, and Bargh et al. 2005). The evidence is mixed. That is, controlled and conscious processing of making social judgments does not always exist, and automatic and preconscious processing depends on context and individual differences (Bargh 1989). Many scholars agree that the question of whether an individual takes automatic or controlled process to make policy judgments is empirical rather than theoretical. Indeed, there are no theories that can lead us to predict with confidence who takes which mode of information processing.

In addressing this question, it is important to distinguish between activation and application of racial predispositions (Bargh 1996; Devine 1989; Fiske 1989; Fazio and Dunton 1994). Activation is automatically determined by the accessibility of the information stored in memory and it is fit to the target object for making judgments. Application refers to use of activated and now available perception or evaluation of the target object. Judgments occur in two stages: (1) a relatively automatic characterization (i.e., activation) stage in which information stored in memory is retrieved and activated and thus ready to be used for judgmental tasks at hand and (2) a more deliberate correction (i.e., application) stage in which the initial characterization of the target object is modified or reinforced in light of contextual and individual constraints on the target object.

Activation of racial predispositions is thought to be normal, given that racism is deeply 
embedded in white American culture (Sears et al. 1997; Kinder and Sanders 1996; Mendelberg 2001), despite lack of empirical grounds to expect automatic activation of racial predispositions for most white Americans. Meanwhile, when individuals are motivated to be correct or unprejudiced, when cognitive resources are sufficient for making judgments, or when egalitarian racial norms are heightened, individuals control the judgmental processes by overriding activated perceptions or evaluations stemming from anti-black attitudes (Devine 1989; Fiske 1989; Monteith and Voils 1998; Gaertner and Dovidio 1986). According to Devine (1989) and Monteith, Sherman, and Devine (1998), the key to the self-censoring process is heightened cognitive engagement with the judgmental tasks at hand, which leads individuals to react consciously against the automatically-activated affective feelings.

Given this literature, it is reasonable to postulate that the impact of racial predispositions on racial policy judgments is moderated by one's attention to judgmental tasks about race matters. After controlling for individual differences especially in antiblack attitudes and political attitudes such as party identification and political ideology, some will succeed in restraining hasty stereotypical responses by heightened cognitive engagement with the judgmental tasks at hand while others will not (see Dovidio et al. 1997; Devine 1989; Devine and Montieth 1993; Fazio and Dunton 1997; Wegener and Petty 1995).

This postulation might be questioned in two ways. One might argue that although a majority of white Americans now censor their negative feelings on something as blatantly prejudiced as opposing a black family moving next door into their neighborhood, some of them also consider it legitimate to oppose affirmative action programs or federal programs to aid blacks, especially since many elites have opened the door by challenging such programs. In another respect, others might argue that it is too early to conclude the validity of the role of cognitive engagement in censoring racial predispositions because this conclusion has been found in laboratory contexts and corroborated by a convenient sample, but not from random surveys of the general population. While there is strong experimental support for censoring processes on a range of racial attitudes, these findings have not been supported by survey research based on large-scale random samples.

An important task is thus to present survey evidence of the significant role that cognitive engagement with the judgmental tasks plays among large, representative samples in the controversial issues like affirmative action programs and federal programs to aid blacks. I will show that survey respondents who have high levels of cognitive engagement tend to less influenced by anti-black attitudes and more likely to 
support affirmative action and federal aid to blacks.

\section{Defining Cognitive Engagement in a Survey Context}

There are many conceptualizations of cognitive engagement including personal relevance, issue involvement, task importance, accountability, and responsibility for message evaluation. All these categories are based on the assumption that individuals who are motivated to engage in judgmental tasks are likely to hold different opinions from those who are not motivated to do so (Chaiken and Trope 1999; Eagly and Chaiken 1993; Petty and Cacioppo 1986, 1990; Eagly and Chaiken 1993). In other words, individuals who consider judgmental tasks important or personally relevant in the survey process are likely to expend cognitive efforts in shaping and expressing their judgments. In addition, given the normative climate in which anti-black attitudes are considered socially undesirable traits, it is reasonable to presume that as one's cognitive engagement with the judgmental tasks associated with race matters increases, he or she is likely to care about automatically activated negative racial considerations.

By cognitive engagement, I refer to the extent to which an individual takes cares about the judgmental tasks that he or she is encountering in the survey processes. A high degree of cognitive engagement reflects conscious, effortful, and controlled engagement with the survey tasks for making judgments on and expressing opinions about policy issue. I will discuss how I operationalized this concept of cognitive engagement in the survey context in the next section.

\section{Data and Measures}

For the analyses I used the 1996 and 2004 National Election Studies (NES). The reason that only two data sets were analyzed is other NES data sets do not contain the questions necessary for measuring cognitive engagement. Since there is no theoretical reason to believe that the hypothesized relationships among the variables of interest in the 1996 NES are different from those in the 2004 NES, I pooled the two data sets for multivariate analysis. For coding schemes of all the measures except cognitive engagement, I followed Sears et al. (1997), which is a robust study that demonstrates the dominant impact of anti-black attitudes on racial policy preferences. Variable codes and coding schemes are provided in Appendix. And descriptive statistics of the variables are presented in Table 1. 
$\langle$ Table 1〉 Descriptive Statistics

\begin{tabular}{|c|c|c|c|c|c|}
\hline & $\mathrm{N}$ & Minimum & Maximum & Mean & Std. Dev. \\
\hline \multicolumn{6}{|l|}{ The 1996 NES } \\
\hline Cognitive Engagement( 4 items; $\alpha=0.453$ ) & 1,648 & 0.05 & 1 & 0.62 & 0.20 \\
\hline Symbolic Racism(2 items) & 1,524 & 2 & 10 & 6.42 & 1.46 \\
\hline Racial Stereotypes(3 items; $\alpha=0.831$ ) & 1,446 & 3 & 21 & 11.57 & 3.02 \\
\hline Party Identification & 1,695 & 1 & 7 & 3.68 & 2.10 \\
\hline Political Ideology & 1,651 & 1 & 5 & 3.48 & 1.84 \\
\hline Knowledge(6 items; $\alpha=0.607)$ & 1,521 & 0 & 6 & 3.68 & 1.62 \\
\hline Education & 1,711 & 1 & 7 & 4.10 & 1.65 \\
\hline Age & 1,714 & 18 & 99 & 47.60 & 17.49 \\
\hline South(dummy) & 1,714 & 0 & 1 & & \\
\hline Federal Assistance & 1,269 & 1 & 7 & 4.69 & 1.62 \\
\hline Affirmative Action & 1,282 & 1 & 5 & 4.21 & 1.35 \\
\hline \multicolumn{6}{|l|}{ The 2004 NES } \\
\hline Cognitive Engagement( 4 items; $\alpha=0.568)$ & 1,155 & 0.12 & 1 & 0.64 & 0.18 \\
\hline Symbolic Racism $(4$ items; $\alpha=0.781)$ & 1,046 & 4 & 20 & 13.40 & 3.99 \\
\hline Racial Stereotypes(3 items; $\alpha=0.802$ ) & 1,066 & 3 & 21 & 11.27 & 2.95 \\
\hline Party Identification & 1,195 & 1 & 7 & 3.88 & 2.09 \\
\hline Political Ideology & 1,156 & 1 & 5 & 3.37 & 1.88 \\
\hline Knowledge(5 items; $\alpha=0.739)$ & 1,066 & 1 & 5 & 2.89 & 1.61 \\
\hline Education & 1,212 & 0 & 7 & 4.30 & 1.61 \\
\hline Age & 1,212 & 18 & 90 & 47.27 & 17.14 \\
\hline South(dummy) & 1,212 & 0 & 1 & & \\
\hline Federal Assistance & 782 & 1 & 7 & 4.82 & 1.63 \\
\hline Affirmative Action & 744 & 1 & 5 & 4.35 & 1.14 \\
\hline
\end{tabular}

Source: The 1996 and 2004 National Election Studies.

\section{Dependent Variables}

For racial policy preferences, two items - federal programs to aid blacks and affirmative action-were tapped. The question wording of the former was "Should we increase or decrease federal spending on programs benefiting blacks." The question wording of the latter was "Are you for or against preferential hiring and promotion of blacks."

The NES codes federal assistance as 1 for "[g]overnment should help blacks" and 7 for "Blacks should help themselves" and affirmative action as 1 for "Favor" and 5 for "Oppose." Thus higher scores represent more opposition to racially targeted policies. 
Data shows that $83 \%$ and $86 \%$ of white respondents oppose affirmative action programs in the 1996 and 2004 NES, respectively. Forty percent and 57\% of whites think that blacks should help themselves in the 1996 and 2004 NES, respectively.

\section{Independent Variables}

\section{(1) The Key Variable: Cognitive Engagement}

A critical task in this study is to develop a measure that can serve as an indicator of cognitive engagement when survey participants respond to questions about the racetargeted public policies. Several items, such as political participation (such as engagement in political discussions with friends and contribution of money to political candidates), political interest (such as campaign interest), and media use seem suitable measures of cognitive engagement. These are all self-reported measures and thus are susceptible to social desirability bias. The presence of a social desirability bias attenuates or inflates relationships between the variables (Fisher 1993). Research that does not take steps to minimize the social desirability bias likely reaches theoretically and practically spurious conclusions (Fisher 1993). And when it comes to race, social desirability bias seriously damages the validity of the estimated relationships among the variables (Krysan 1998; Cook and Campbell 1979; Runkel and McGrath 1972). As Fisher (1993) contends, it is necessary to be cautious when adopting self-reported measure that is especially related to socially desirable attributes as dependent or independent variables.

Regarding the tendency of survey respondents' exaggeration in the items related to socially desirable traits, the interviewer's ratings of a respondent's "general level of information about politics and public affairs" have previously been used to measure political knowledge (Bartels 1996; Gay 2002). It turns out that despite its subjectivity, this item is a surprisingly good measure of political knowledge (Zaller 1986; see also Luskin and Bullock 2004). As Zaller (1986) indicates, "these five-point items [of interviewers' ratings about respondents' level of political knowledge-my addition] were very powerful, and that they were essentially free of contamination by interviewers who might be biased in favor of higher status respondents" (17).

Given this result, it seems reasonable to use other interviewer ratings of the respondent attitudes in the survey process. The items, such as the respondent's interest in the interview, the respondent's sincerity in their judgmental tasks, and the respondent's cooperation in the survey processes, reflect how sincerely, cooperatively, and actively the respondent engages in the judgmental tasks through the interview 
process. These items can be considered a good proxy for the respondent's general level of cognitive engagement with the survey questions and the judgmental tasks. That is, survey respondents with the attitudes of high levels of sincerity, cooperation, and interest are likely to consciously involve themselves in their opinion formation processes rather than produce hasty responses through automatic, unconscious, effortless information processes.

In another respect, however, these items are a broad, general-level estimation of the respondent's involvement in the whole survey process, not a domain-specific estimation of attitudes. So it is needed to construct a measure of cognitive engagement specific to the respondent's attitudes associated with race matters. To this end, I took the question of "[h]ow important is the issue of aid to blacks to the respondent personally," which measures personal importance of the issue of aid to blacks. Given the finding that individuals try to cognitively engage issues that are personally important (see Maheswaran and Chaiken 1991), it is legitimate to assume that this item functions as an issue-specific weight to race matters.

To operationalize the four items (i.e., three interviewer's ratings and personal importance of the issue of aid to blacks), I first summed the three instrumental items of the interviewer ratings of the participants involvement in, cooperation with, and sincerity in the survey processes, which are significantly correlated $(\alpha=0.686)$. The three instrumental items represent the general level of cognitive engagement with the survey processes. Then, I multiplied the sum of the three instrumental items by the personal importance of aid to blacks positing a joint effect of cognitive engagement with the survey tasks in general and personal importance of aid to blacks on racial policy preferences. That is, the effect of the three instrumental items on racial policy preferences is greater at higher levels of perceived importance of the issue of aid to blacks and the effect of personal importance of aid to blacks on racial policy preferences is greater for those who are highly engaged in the survey processes in general. This postulation is theoretically sound and supported by the significant correlation of the sum of the three instrumental items and the measure of personal importance of the issue of aid to blacks ( $r=0.054, p<0.03$ in the $1996 \mathrm{NES} ; r=0.07, p<0.024$ in the 2004 NES).

To test the performance of the measure of cognitive engagement, I examined the correlations between the measure of cognitive engagement and other measures that are supposedly related to cognitive engagement, such as self-reported campaign interest, the reviewer's estimation of the respondent's intelligence, the intensity of political ideology, and turnout. Performance of a measure depends on how it shows as stable and 
consistent relationships with other measures as is expected by theory. As presented in Table 2, my measure of cognitive engagement consistently shows significant relationships with relevant attitudinal variables. Those who are rated more knowledgeable by the interviewer, are more interested in political campaigns, hold a strong political ideology, and participate in a poll are more likely to highly engage themselves in the judgmental tasks during the survey processes.

〈Table 2〉 Correlations between Cognitive Engagement and Other Factors

\begin{tabular}{l|c|c}
\hline \multicolumn{1}{c|}{ Factors } & The 1996 NES & The 2004 NES \\
\hline Political Knowledge & $0.093^{* * *}$ & $0.171^{* * *}$ \\
& $(1,466)$ & $(1.017)$ \\
\hline Interviewers' Ratings of & $0.208^{* * *}$ & $0.285^{* * *}$ \\
Respondents' Intelligence & $(1,647)$ & $(1,155)$ \\
\hline Campaign Interest & $0.239^{* * *}$ & $0.255^{* * *}$ \\
& $(1,479)$ & $(1,017)$ \\
\hline Intensity of Political Ideology & $0.058^{*}$ & $0.185^{* * *}$ \\
& $(1,551)$ & $(1,141)$ \\
\hline \multirow{2}{*}{ Turnout } & $0.127^{* * *}$ & $0.149^{* * *}$ \\
& $(1,479)$ & $(1,155)$ \\
\hline
\end{tabular}

Notes: 1. Entries are Pearson correlation coefficients. 2. Valid number of cases is in parentheses. $* * * p<.001 ; * * p<.01 ; * p<.05$.

I also examined if the item of issue importance regarding aid to blacks covaries with competing explanatory variables (i.e., symbolic racism and racial stereotypes). If this is the case, the importance of aid to blacks and cognitive engagement represents the same attitudes domain as symbolic racism and racial stereotypes. The results presented in Table 3 show that individual items that make up cognitive engagement are not correlated with the symbolic racism or racial stereotypes with two exceptions. It is worth emphasizing that the personal importance of aid to blacks is not correlated with the competing independent variables, symbolic racism and racial stereotypes. Finally, the composite measure of cognitive engagement is not correlated with symbolic racism and racial stereotypes. This indicates that my measure of cognitive engagement does not share the attitudinal dimension to which symbolic racism and racial stereotypes belong. 
〈Table 3〉 Correlations between the Items Incorporated in Cognitive Engagement and Symbolic Racism/Racial Stereotypes

\begin{tabular}{l|c|c|c|c}
\hline \multirow{2}{*}{ Cooperation } & \multicolumn{2}{|c|}{ The 1996 NES } & \multicolumn{2}{c}{ The 2004 NES } \\
\cline { 2 - 5 } & $\begin{array}{c}\text { Symbolic } \\
\text { Racism }\end{array}$ & $\begin{array}{c}\text { Racial } \\
\text { Stereotypes }\end{array}$ & $\begin{array}{c}\text { Symbolic } \\
\text { Racism }\end{array}$ & $\begin{array}{c}\text { Racial } \\
\text { Stereotypes }\end{array}$ \\
\hline \multirow{2}{*}{ Sincerity } & $\begin{array}{c}0.012 \\
(0.529)\end{array}$ & -0.049 & $-0.100^{* *}$ & -0.032 \\
& 0.015 & -0.021 & $-0.112^{* *}$ & -0.023 \\
\hline \multirow{2}{*}{ Interest } & $(0.590)$ & $(0.441)$ & $(0.002)$ & $(0.524)$ \\
\hline \multirow{2}{*}{ Importance of Aid to Blacks } & $0.063^{*}$ & -0.041 & 0.016 & 0.000 \\
\hline \multirow{2}{*}{ Cognitive Engagement } & $(0.021)$ & $(0.141)$ & $(0.670)$ & $(0.994)$ \\
\hline
\end{tabular}

Notes: 1 . Entries are Pearson correlation coefficients. 2. $t$-ratio is in parentheses. $* * * p<.001 ; * * p<.01 ; * p<.05$.

\section{(2) Competing Variables}

I included two competing explanatory variables, symbolic racism and racial stereotypes, to estimate the impact of racial predispositions on racial policy preferences. For this, I followed the measures used in previous studies. Symbolic racism consists of the four attitude domains - denial of continuing racial discrimination, blacks should work harder, blacks' excessive demands, and undeserved advantage for blacks (see Sears et al. 1997).

To measure racial stereotypes, I followed Sears et al. (1997). Racial stereotypes consists of the respondent's ratings of blacks on 7-point scales whose endpoints are that blacks are hard-working-lazy, intelligent-unintelligent, and trustworthy —untrustworthy.

\section{(3) Control Variables}

I also included party identification, political ideology, and socioeconomic status variables including age, gender, and region, which are generally expected to affect racial policy preferences (Sears et al. 1997; Kinder and Sanders 1996). 


\section{Models}

I ran two models using a least-square estimator. Model (1) replicates Sears et al. (1997) as a baseline model by estimating the impacts of symbolic racism and racial stereotypes on the racial policy preferences. ${ }^{3)}$ The functional form of the model is as follows.

$$
\begin{aligned}
& \text { Racial Policy Preferences }=\alpha+\beta_{1}{ }^{*} \text { Symbolic Racism }+\beta_{2}{ }^{*} \text { Racial Stereotype }+\beta_{3}{ }^{*} \text { Party } \\
& \text { Identification }+\beta_{4}{ }^{*} \text { Political Ideology }+\beta_{5}{ }^{*} \text { Age }+\beta_{6}{ }^{*} \text { South }+\beta_{7}{ }^{*} \text { Male }+u
\end{aligned}
$$

Where, $\alpha$ is constant, $\beta$ s are ordinary least-squares regression coefficients, and $u$ is an error term; The model was run on federal assistance to blacks and affirmative action, separately; and age, south, and male are dummy variable. Details of coding schemes for other variables are presented in Appendix.

Then, to test if the effect of racial predispositions on racial policy preferences is moderated by cognitive engagement, Model (2) incorporates the variables of cognitive engagement and two interaction terms of cognitive engagement by symbolic racism and by racial stereotype. The functional form of the model is as follows.

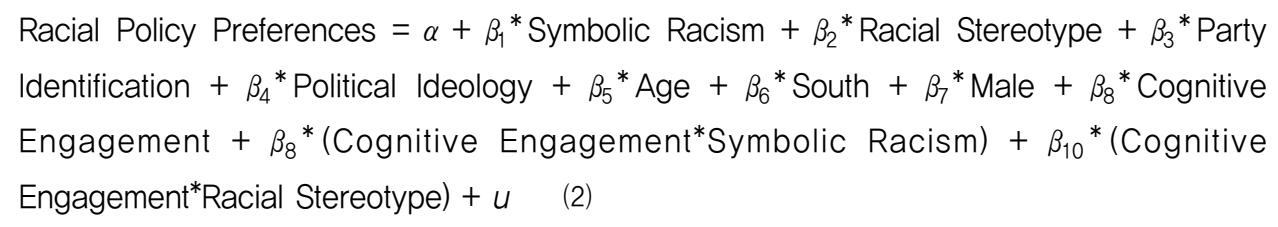

3) One may argue that there is a problem of multicollinearity because symbolic racism and racial stereotype, which are closely correlated with one another (in the $1996 \mathrm{NES}, r=.0885, p<.00008$; in the $2004 \mathrm{NES}, r=.2568, p<.0000$ ), are tapped together in the model. In general, multicollinearity is present when there are exact linear relationships between the independent variables and when there are as many observations as independent variables. The OLS estimator in the presence of multicollinearity remains unbiased and is still BLUE. In fact, the OLS estimator remains all its desirable properties. The major undesirable consequence of multicollinearuty is that the variances of the OLS estimates of the parameters of the collinear variables are quite large. The general remedy to the presence of multicollinearity is to do nothing if the estimated equation is to be used for prediction purpose. Another remedy is to incorporate more observations(see Kennedy1998). In my analysis there are enough number of observations(i.e., at least more than 1789). Furthermore, theoretically symbolic racism and racial stereotype represent different attitudinal dimensions(see note 1 on page 1). That is, the two concepts are closely related but are not in exact linear relationship.

4) Standardized value is used for symbolic racism because it is measured based on two questions in the 1996 NES while four questions in the 2004 NES. 
Where, $\alpha$ is constant, $\beta \mathrm{s}$ are ordinary least-squares regression coefficients, and $\mathrm{u}$ is an error term; The model was run on federal assistance to blacks and affirmative action, separately; age, south, and male are dummy variable; and cognitive engagement and two interaction terms are incorporated. Details of coding schemes for other variables are also presented in Appendix.

In Model (2), I expect that cognitive engagement will be significant. I also expect that the interaction terms will be significant, indicating that the impact of symbolic racism or racial stereotype is dependent on one's level of cognitive engagement. That is, individuals that are highly involved in racial issues will be more likely to support racetargeted policies.

\section{Results}

As is reported in Table 4, the results of OLS regressing the two policy preferences as the dependent variables onto the explanatory variables support my argument and yield a better understanding of the formation of racial policy preferences. First, as expected, party identification and political ideology play significant roles in determining racial policy preferences in both Models (1) and (2). Republicans and conservatives are more likely than Democrats and liberals to oppose racially targeted policies.

Second, as expected, symbolic racism and racial stereotypes show robust, positive impacts on the dependent variables, which indicates that respondents with more symbolic racism and racial stereotypes are more likely to oppose federal aid to blacks and preferential hiring and promotion of blacks.

Third, Model (2) reveals that the coefficient of symbolic racism is not statistically significant while the coefficient of racial stereotypes is significant. These results indicate that the impact of anti-black attitudes decrease when cognitive engagement is included in the model. In contrast, cognitive engagement shows a statistically significant effect.

Fourth, the interaction between cognitive engagement and symbolic racism is significantly related to one's position on federal assistance and affirmative action, which indicates that magnitude of the effect of symbolic racism changes with different levels of cognitive engagement. The existence of significant joint effect of symbolic racism and cognitive engagement suggests that Model (1) provides an inaccurate estimation of the true relationships between the dependent and independent variables. In addition, given that the adjusted R squares of Model (2) are greater than those of Model (1), Model (2) is a 
〈Table 4〉 The Impact of Cognitive Engagement and Other Variables on Racial Policies, Pooled Data of the 1996 and 2004 NES

\begin{tabular}{|c|c|c|c|c|}
\hline & Federal & sistance & Affirma & Action \\
\hline & Model (1) & Model (2) & Model (1) & Model (2) \\
\hline Symbolic Racism & $\begin{array}{c}0.059 * * * \\
(0.008)\end{array}$ & $\begin{array}{c}0.004 \\
(0.026)\end{array}$ & $\begin{array}{c}0.054^{* * * *} \\
(0.016)\end{array}$ & $\begin{array}{l}-0.004 \\
(0.030)\end{array}$ \\
\hline Racial Stereotypes & $\begin{array}{c}0.123^{* * *} \\
(0.012)\end{array}$ & $\begin{array}{c}0.078 * * \\
(0.025)\end{array}$ & $\begin{array}{c}0.095 * * * \\
(0.014)\end{array}$ & $\begin{array}{c}0.092 * * \\
(0.029)\end{array}$ \\
\hline Cognitive Engagement (C.E.) & & $\begin{array}{c}-0.027 * * * \\
(0.002)\end{array}$ & & $\begin{array}{c}-0.026^{* * *} \\
(0.003)\end{array}$ \\
\hline C.E. * Symbolic Racism & & $\begin{array}{c}0.251^{* * *} \\
(0.041)\end{array}$ & & $\begin{array}{c}0.255^{* * *} \\
(0.046)\end{array}$ \\
\hline C.E. ${ }^{*}$ Racial Stereotypes & & $\begin{array}{c}0.041 \\
(0.032)\end{array}$ & & $\begin{array}{l}-0.022 \\
(0.038)\end{array}$ \\
\hline Party Identification & $\begin{array}{c}0.097^{* * * *} \\
(0.019)\end{array}$ & $\begin{array}{c}0.127^{* * * *} \\
(0.019)\end{array}$ & $\begin{array}{c}0.087^{* * *} \\
(0.022)\end{array}$ & $\begin{array}{c}0.116^{* * *} \\
(0.022)\end{array}$ \\
\hline Political Ideology & $\begin{array}{c}0.124^{* * * *} \\
(0.021)\end{array}$ & $\begin{array}{c}0.072^{* * *} \\
(0.021)\end{array}$ & $\begin{array}{c}0.144^{* * * *} \\
(0.026)\end{array}$ & $\begin{array}{c}0.095^{* * * *} \\
(0.026)\end{array}$ \\
\hline Age & $\begin{array}{c}-0.007^{* * *} \\
(0.002)\end{array}$ & $\begin{array}{c}-0.005^{* *} \\
(0.002) \\
\end{array}$ & $\begin{array}{l}-0.003 \\
(0.090) \\
\end{array}$ & $\begin{array}{c}-0.0009 \\
(0.002) \\
\end{array}$ \\
\hline South & $\begin{array}{l}-0.070 \\
(0.075)\end{array}$ & $\begin{array}{l}-0.121 \\
(0.074) \\
\end{array}$ & $\begin{array}{l}-0.339 \\
(0.090) \\
\end{array}$ & $\begin{array}{c}-0.369 * * * \\
(0.089)\end{array}$ \\
\hline Male & $\begin{array}{c}0.011 \\
(0.069)\end{array}$ & $\begin{array}{c}0.023 \\
(0.067)\end{array}$ & $\begin{array}{l}-0.021 \\
(0.083)\end{array}$ & $\begin{array}{l}-0.007 \\
(0.082)\end{array}$ \\
\hline Adj. $R^{2}$ & 0.177 & 0.235 & 0.112 & 0.153 \\
\hline $\mathrm{N}$ & 1816 & 1789 & 1860 & 1823 \\
\hline
\end{tabular}

Source: The 1996 and 2004 National Election Studies.

Notes: 1. Entries are OLS regression coefficients with standard error in parentheses. 2. Positive sign indicates that higher values of the variables produce more opposition to the federal assistance to blacks and affirmative action. 3. Party Identification is coded 1 as Democrat, 3 as Independent, and 5 as Republican; Political Ideology is coded 1 as liberal, 3 as moderate, and 5 as conservative. 4. South and Male are dummy variables, coded 1 as south and male. 4. Political Knowledge was initially entered into the analysis, along with Cognitive Engagement. Significant effects were found but it is dropped for model simplicity.

$* * * p<.001 ; * * p<.01 ; * p<.05$.

more accurate account for racial policy preferences and explains more of the variation in the dependent variables.

Finally, the cognitive engagement-symbolic racism coefficient of the interaction term of symbolic racism and cognitive engagement is positive. That is, the higher the symbolic racism, the greater the effect of cognitive engagement on racial policy 
preferences. By the same token, the higher the cognitive engagement, the greater the effect of symbolic racism on racial policy preferences.

Figures 1 and 2 present substantive effects of the cognitive engagement by symbolic racism. To do this, I divided respondents between those with high and low levels of cognitive engagement. High cognitive engagement includes those who are one standard deviation above the mean of cognitive engagement and low cognitive engagement includes those who are one standard deviation below the mean. ${ }^{5}$ Predicted values of the dependent variable at different levels of symbolic racism are then calculated for those who with high and low levels of cognitive engagement.

〈Figure 1〉 Predicted Values of Federal Aid to Blacks for those who belong to high and low levels of Cognitive Engagement (C.E.) by Symbolic Racism



Notes: 1. Federal Aid to Blacks is coded 1 as strong supporter and 7 as strong opponents. 2. Symbolic Racism is coded 0 for non racists and 20 for racists. 3. Those who are attentive(circle and gray dots) are more likely to support Federal Aid to Blacks if they hold the same level of Symbolic Racism as those who are not attentive(square and black dots) do. 4. Predicted values are calculated based on Model (2).

5) No theoretical standard exists for deciding what level of cognitive engagement is high(and low). The actual cut points that I took here are arbitrary. 
〈Figure 2) Predicted Values of Preferential Hiring and Promotion of Blacks for those who belong to high and low levels of Cognitive Engagement (C.E.) by Symbolic Racism

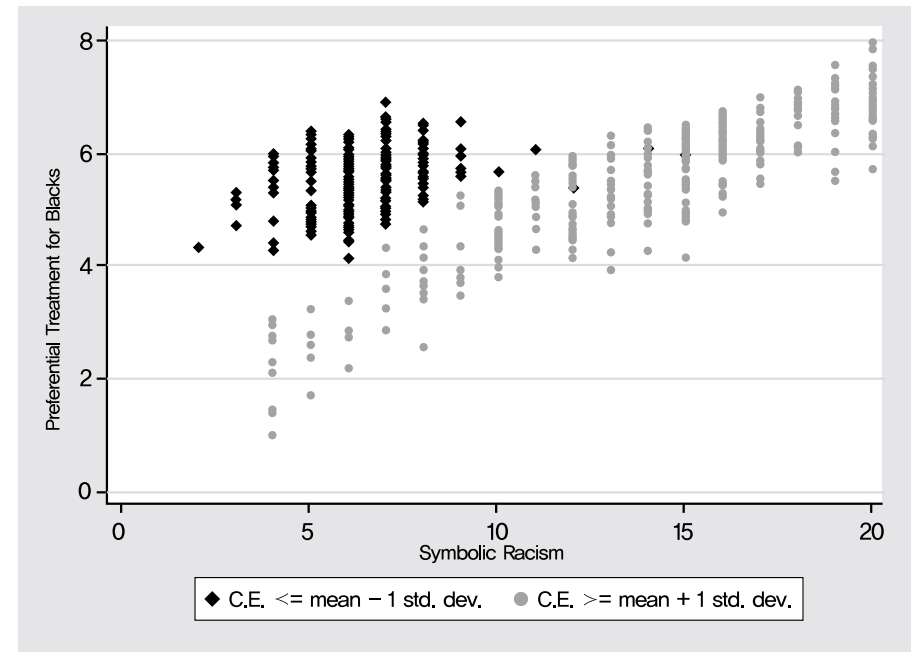

Notes: 1. Federal Aid to Blacks is coded 1 as strong supporter and 7 as strong opponents. 2. Symbolic Racism is coded 0 for non racists and 20 for racists. 3 . Those who are attentive(circle and gray dots) are more likely to support Federal Aid to Blacks if they hold the same level of Symbolic Racism as those who are not attentive(square and black dots) do. 4. Predicted values are calculated based on Model (2).

The results, as illustrated in Figures 1 and 2, reveal that those who belong to high level of cognitive engagement are more likely than with low levels of cognitive engagement to support federal aid to blacks and preferential hiring and promotion of blacks at the same level of symbolic racism. More precisely, those with high levels of cognitive engagement are more likely than those with low levels of cognitive engagement to moderate their opposition of race-targeted policies when racial dispositions are relatively weak. Thus, among those who are low on the racism scale, moving from low to high level of cognitive engagement induces more support for racetargeted policies.

\section{Discussion}

There are at least four noteworthy implications that warrant more discussion. First, expressing racial policy preferences does not seem to be totally out of control as previously thought including theories of automatic and controlled processes of decision- 
making. Individuals who hold higher levels of cognitive engagement with the judgmental tasks in the survey processes are significantly less likely to be influenced by their racial predispositions and tend to support race-targeted public policies.

Second, racial predispositions are persevering, but they may not be neither immutably nor indelibly so. The impact of racial predispositions on racial policy preferences vary according to levels of cognitive engagement with the judgmental tasks. Racial predispositions are not a cross-cutting, dominant factor that drives racial policy preferences. More precisely, symbolic racism means different things to those who are more or less cognitively engaged in judgmental tasks regarding race matters as well as to liberals-Democrats and conservatives-Republicans.

Third, previous models that do not take cognitive engagement into account when explaining racial policy preferences are at least under-specified and potentially misleading. Racial policy preferences of white Americans are better predicted when different levels of cognitive engagement with judgmental tasks are taken into account.

Finally, laboratory studies have established that controlled forms of information processing or heightened attention to judgmental tasks is important for overriding an automatic, race-biased response. But this finding has never been corroborated by large-scale survey data. The analyses here benefit from something missing from previous experimental designs: external validity from a random, representative sample of the general population. 


\section{Appendix: Variables Numbers and Coding Schemes for the 1996 and 2004 NES}

The 1996 and 2004 (advance release file) NES data is drawn from ICPSR website at http://www.icpsr.umich.edu. The following list provides variable numbers for all variables used in the analyses. For each variable, the numbers started with v96 corresponds to the 1996 NES data and the numbers started with v04 represents the variables in the 2004 NES data. The coding scheme and descriptive statistics are also presented as follows.

\section{Dependent Variables:}

\section{Federal Aid to Blacks: v961210, v043158}

Affirmative Action: v961209, v045207a

The NES codes Federal Assistance with 1 for "Government should help blacks" and 7 for "Blacks should help themselves" and Affirmative Action with 1 for "Favor" and 5 for "Oppose." Thus higher scores represent more opposition to racially targeted policies.

Question wording of affirmative action was that "Some people say that because of past discrimination, blacks should be given preference in hiring and promotion. Others say that such preference in hiring and promotion of blacks is wrong because it gives blacks advantages they haven't earned. What about your opinion -- are you FOR or AGAINST preferential hiring and promotion of blacks?" And, question wording of Federal aid to blacks was that "Some people feel that the government in Washington should make every effort to improve the social and economic position of blacks. (Suppose these people are at one end of a scale, at point 1). Others feel that the government should not make any special effort to help blacks because they should help themselves. (Suppose these people are at the other end, at point 7). And, of course, some other people have opinions somewhere in between, at points $2,3,4,5$, or 6 . Where would you place YOURSELF on this scale, or haven't you thought much about this?

\section{Independent Variables:}

Attentiveness: v960069, v960073, v960074, v960489, v043402, v043406, v043407, v043159

R's Cooperation and Interest in the interview are 5-point scale and R's Sincerity is 3point scale. The NES codes these variables with 1 for high cooperation and interest and with 5 for low cooperation and interests and with 1 completely sincere and with 3 for often seem to be insincere. I recoded the sincerity variable into 5-point scale and all the three variables in reverse order. Thus, in my analyses, for R's cooperation and interest, 
1=very poor and low, 2=poor and below average, 3=fair and average, 4=good and above average, $5=$ =very good and very high; and for R' s sincerity, 1=often seem to be insincere, $3=$ usually sincere, $5=$ completely sincere.

The question wording of "importance of aid to blacks" reads: "Some people feel that the government in Washington should make every effort to improve the social and economic position of blacks. Others feel that the government should not make any special effort to help blacks because they should help themselves. How important is this issue to you?" This question was courted in the 1996 (v960489) and 2004 NES (v043159) but not in others. This variable on $1-$ to $^{-5}$ scale was also recoded in reverse order: $1=$ not important, $2=$ not too important, $3=$ somewhat important, 4=very important, $5=$ =xtremely important. The composite measure of attentiveness was standardized.

\section{Symbolic Racism: v961230, v961231, v045193, v045194, v045195, v045196}

The items from the 2004 NES are (1) The history of slavery and discrimination makes it more difficult for blacks to succeed; (2) If blacks would only try harder they could be just as well off as whites; (3) Blacks should work their way up like other racial groups; and (4) Blacks have gotten less then they deserve. The items from the 1996 NES are: (1) We have gone too far in pushing equal rights in this country; and (2) One of the big problems in this country is that we don't give everyone an equal change.

Each variable is 5 -point scale, 1 for agree to 5 for disagree. I recoded the variables, except for v045194 and v045195, in reverse order. Thus higher scores indicate more symbolic racism. In the 1996 NES, I used 2 items of symbolic racism, thus as shown in the table below, the measure of symbolic racism ranges from 2 to 10. In the 2004 NES, since 4 items are used, it ranges from 0 to 20.

\section{Stereotypes: v961312, v961315, v961318, v045223, v045227, v045231}

Each variable is 7-point scale, 1=hardworking/intelligent/trustworthy, 7=lazy/ unintelligent/untrustworthy. The measure of stereotypes is the sum of the three variables.

Political Knowledge: v961189, v961190, v961191, v961192, v961072, v961073, v045163, v045164, v045165, v045089, v045090

This measure was based on factual knowledge items of identification questions (the vice-president, the Chief of Justice of the Supreme Court, the Russian President (or the British Prime Minister), and the Speaker of the House--the 1996 NES only) and party 
control of the House and the Senate. Correct answer is coded 1 and incorrect answer or refuse to answer are coded 0 . Each variable is summed up for the measure of political knowledge.

\section{Party Identification: v960420, v043116}

A 7-point scale is used: 1=Strong Democrat, 2=Weak Democrat, 3=Leaning Democrat, 4=Independent, 5=Leaning Republican, 6=Weak Republican, 7=Strong Republican.

\section{Ideology: v960369, v043086}

A 5-point scale is used: 1=Liberal, 3=Moderate, 5=Conservative.

Education: v960610, v043254

Age: v960605, v043250

Male: v960066, v043411

coded $1=$ Male, $0=$ Female

South: v960109, v041203

coded $1=$ South (10 southern states), $0=$ Non-South 


\section{REFERENCES}

Bargh, J.A. 1994. "The Four Horseman of Automaticity: Awareness, Efficiency, Intention, and Control in Social Cognition.” In Wyer R.S.Jr., and T.K. Srull. 1994. eds. Handbook of Social Cognition. Hillsdale, NJ: Erlbaum.

Bargh, J.A. 1999. "The Cognitive Monster." In Chaiken, Shelly, and Yaacov Trope. 1999. eds. Dual-Process Theories in Social Psychology. New York: Guilford Press.

Bartels, Larry M. "Uninformed Votes: Information Effects in Presidential Elections." American Journal of Political Science 40(1): 194-230.

Bobo, Lawrence, and Vincent L. Hutchings. 1996. "Perceptions of Racial Group Competition: Extending Blumer's Theory of Group Position to a Multiracial Social Context." American Sociological Review 61(6):951-72.

Chaiken, Shelly, and Yaacov Trope. 1999. eds. Dual-Process Theories in Social Psychology. New York: Guilford Press.

Delli Carpini, Michael X., and Scott Keeter. 1998. What Americans Know about Politics and Why It Matters. New Haven: Yale University Press.

Devine, Patricia G. 1989. "Stereotypes and Prejudice: Their Automatic and Controlled Components." Journal of Personality and Social Psychology 56:5-18.

Devine, Patricia G., E. Ashby Plant, David M. Amodio, Eddie Harmon-Jones, and Stephanie L. Vance. 2002. "The Regulation of Explicit and Implicit Race Bias: The Role of Motivations to Respond Without Prejudice." Journal of Personality and Social Psychology 82(5):835-848.

Devine, Patricia G., and M.J. Monteith.1993. "The Role of Discrepancy Associated Affect in Prejudice Reduction." in D.M. Mackie and D.L. Hamiloton (eds.), Affect, Cognition, and Stereotyping: Interactive Processes in Intergroup Perception. San Diego, CA: Academic Press.

Eagly, Alice H., and Shelly Chaiken. 1993. The Psychology of Attitudes. Harcourt College Publishers.

Fazio, Russell H., David M. Sanonmatsu, Martha C. Powell, and Frank R. Kardes. 1986. "On Automatic Activation of Attitudes" Journal of Personality and Social Psychology. 50(2):229-238.

Fazio, Russell H., and Bridget C. Dunton. 1997. "Categorization by race: The Impact of Automatic and Controlled Components of Racial Prejudice." Journal of Experimental Social Psychology 33:451-470. 
Fazio, Russell H., and Michael A. Olson. 2003. "Implicit Measures in Social Cognition Research: Their Meaning and Use.” Annual Review of Psychology 54:297-327.

Federico, Christopher M. and Jim Sidanius. 2002. "Sophistication and the Antecedents of Whites' Racial Policy Attitudes: Racism, Ideology, and Affirmative Action in America.” Public Opinion Quarterly 66: 145 - 176.

Fisher, R. J. 1993. Social desirability bias and the validity of indirect questioning. Journal of Consumer Research, 20: 303-315.

Gay, Claudine. 2002. "Spirals of Trust? The Effect of Descriptive Representation on the Relationship between Citizens and Their Government." American Journal of Political Science, 46(4): 717-732.

Gilens, Martin. 1995. "Racial Attitudes and Opposition to Welfare." Journal of Politics 57:994-1014.

Gilens, Martin. 1998. "Racial Attitudes and Race-Neutral Social Policies: White Opposition to Welfare and the Politics of Racial Inequality." In Perception and Prejudice, eds. Jon Hurwitz and Mark Peffley. New Haven, CT: Yale University Press. Pp. 171-201.

Gilens, Martin. 1999. Why Americans Hate Welfare. Chicago: University of Chicago Press. Kinder, Donald R., and Tali Mendelberg. 1995. "Cracks in American Apartheid: The Political Impact of Prejudice among Desegregated Whites.” Journal of Politics 57:402-24.

Kinder, Donald R., and Lynn M. Sanders. 1990. "Mimicking Political Debate with Survey Questions: The Case of White Opinion on Affirmative Action for Blacks." Social Cognition 8:73-103.

Kinder, Donald R., and Lynn M. Sanders. 1996. Divided By Color: Racial Politics and Democratic Ideals. Chicago, IL: University of Chicago Press.

Kuklinski, James H., Paul J. Quirk, Jennifer Jerit, and Robert F. Rich. 2001. "The Political Environment and Citizen Competence." American Journal of Political Science 45(2): 410-424.

Luskin, Robert C., and John Bullock. 2004. "Re(: )Measuring Political Sophistication.” Unpublished manuscript.

Maheswaran, D., and Shelly Chaiken. 1991. "Prompting Systematic Processing in Low Motivation Settings: Effect of Incongruent Information on Processing and Judgment." Journal of Personality and Social Psychology 61:13-25.

Mendelberg, Tali. 2001. The Race Card: Campaign Strategy, Implicit Messages, and the Norm of Equality. Princeton, NJ: Princeton University Press. 
Nelson, Thomas E. 2004. "Policy Goals, Public Rhetoric, and Political Attitudes.” Journal of Politics 66(2): 581-605.

Peffley, Mark, Jon Hurwitz, and Paul M. Sniderman. 1997. "Racial Stereotypes and Whites' Political Views of Blacks in the Context of Welfare and Crime." American Journal of Political Science 41(1): 30-60.

Petty, Richard E., John T. Cacioppo, J.A. Kasmer. 1988. "The Role of Affect in the Elaboration Likelihood Model of Persuasion.” In L. Donohew, H. E. Sypher, \& E. T. Higgins (Eds.), Communication, Social Cognition, and Affect. Hillsdale, NJ: Erlbaum.

Schuman, Howard, Charlotte G. Steeh, and Lawrence Bobo. 1997. Racial Attitudes in America: Trends and Interpretations. Cambridge, MA: Harvard University Press.

Sears, David O., Jim Sidanius, and Lawrence Bobo. 2000. Racialized Politics: The Debate about Racism in America. Chicago: University of Chicago Press.

Sears, David O., Coletter Van Laar, Mary Carrillo, and Rick Kosterman. 1997. "Is It Really Racism?: The Origins of White Americans' Opposition to Race-Targeted Policies." Public Opinion Quarterly 61(1):16-53.

Sears, David O., and Jack Citrin. 1985. Tax Revolt: Something for Nothing in California. Cambridge, MA: Harvard University Press.

Sidanius, Jim, Seymour Feshbach, Shana Levin, and Felicia Pratto. 1997. "The Interface Between Ethnic and National Attachment: Ethnic Pluralism or Ethnic Dominance?" Public Opinion Quarterly 61: 102-133.

Singer, Eleanor. 2002. "The Use of Incentives to Reduce Nonresponse in Household Surveys.” In Survey Nonresponse, ed. R.M. Groves, D.A, Dillman, J.L. Eltinge, and R.J.A. Little, New York: Wiley.

Sniderman, Paul M., and Thomas Piazza. 1993. The Scar of Race. Cambridge, MA: Harvard University Press.

Stoker, Laura. 1998. “Understanding Whites' Resistance to Affirmative Action: The Role of Principled Commitments and Racial Prejudice." In Perception and Prejudice: Race and Politics in the United States, ed. Hurwitz, Jon, and Mark Peffley. New Haven: Yale University Press.

Wegener, D.T., and Richard E. Petty. 1995. "Flexible Correction Processes in Social Judgment: The Role of Nailve Theories in Corrections for Perceived Bias." Journal of Personality and Social Psychology. 68:36-51.

Zaller, John R. 1992. The Nature and Origins of Mass Opinion. Cambridge University Press. 